\title{
Radiocarbon
}

1995

\section{RADIOCARBON DATING EVIDENCE FOR MAMMOTHS ON WRANGEL ISLAND, ARCTIC OCEAN, UNTIL 2000 BC $^{1}$}

\author{
S. L. VARTANYAN \\ Wrangel Island State Reserve, 686870 Ushakovskoye, Magadan Region, Russia
}

KH. A. ARSLANOV, T. V. TERTYCHNAYA and S. B. CHERNOV

Geographical Research Institute, St. Petersburg State University, Sredniy Prospect 41

199004 St. Petersburg, Russia

\begin{abstract}
Radiocarbon dating results of mammoth tusks, teeth and bones collected on Wrangel Island between 1989 and 1991 reveal a unique mammoth refugium during the Holocene. We used an improved chemical procedure to obtain and purify collagen from bone. Benzene synthesized from the samples was measured using a liquid scintillation counter. The validity of our data has been confirmed by the results of our measurements on two international control sample series (IAEA and TIRI) and by parallel measurements of Wrangel Island mammoth remains at other laboratories.
\end{abstract}

\section{INTRODUCTION}

The systematic ${ }^{14} \mathrm{C}$ dating of wooly mammoth (Mammuthus primigenius) remains, carried out in our laboratory for many years, should help determine the cause or causes of the mammoths' extinction. Among the remains found well preserved in permafrost are those of the mammoths known as Shandrin, Terekhtyakh, Magadan, Khatanga and Yuribei (Arslanov et al. 1980, 1982). Many scientists assume that the most probable cause of extinction was an abrupt change in climatic conditions during the Pleistocene/Holocene transition, a period corresponding to the ${ }^{14} \mathrm{C}$ dates of the youngest mammoths of Siberia. Others invoke an anthropogenic agency, or a combination of cultural and paleoclimatic forces. An exhaustive explanation of the cause is not yet possible. In the Late Pleistocene, the range of mammoths shifted northward. In the Crimea and the Caucasus, mammoths became extinct $>20-30 \mathrm{ka}$ ago; on the Russian plain they were still present $c a .13 \mathrm{ka}$ ago (Arslanov et al. 1972; Lavrov and Sulezhytsky 1992). Based on ${ }^{14} \mathrm{C}$ ages, the latest mammoth remains found in western Europe (northern France, Switzerland and Great Britain) also date to 12-13 ka ago, when their remains become relatively uncommon (see Stuart 1991).

The last refugia of the mammoth were thought to be the Siberian Arctic and the Arctic islands, including Gydan and Taimyr Peninsulas and the Severnaya Zemlya Archipelago. The youngest ${ }^{14} \mathrm{C}$ date our laboratory obtained for the Yuribei mammoth (Gydan peninsula, Siberia) was 10,000 \pm 70 BP, based on stomach contents (plant debris). Similar results were later obtained by L. Sulerzhytsky (Geological Institute of the Russian Academy of Sciences, Moscow) for tusk and tooth remains of mammoths of the Taimyr Peninsula, Siberia (Lavrov and Sulerzhytsky 1992). ${ }^{14} \mathrm{C}$ data thus indicated that mammoths became extinct, even in the refugia of the continental Siberian Arctic, ca. 9.7-10 ka ago. However, in 1990, our first five dates for mammoth remains from Wrangel Island were all of Holocene age, ranging from $7390-4740 \mathrm{BP}$ (Vartanyan et al. 1992). This surprisingly young estimate prompted us to continue investigations at that location.

\footnotetext{
${ }^{1}$ This paper was presented at the 15th International Radiocarbon Conference, 15-19 August 1994, Glasgow, Scotland
} 


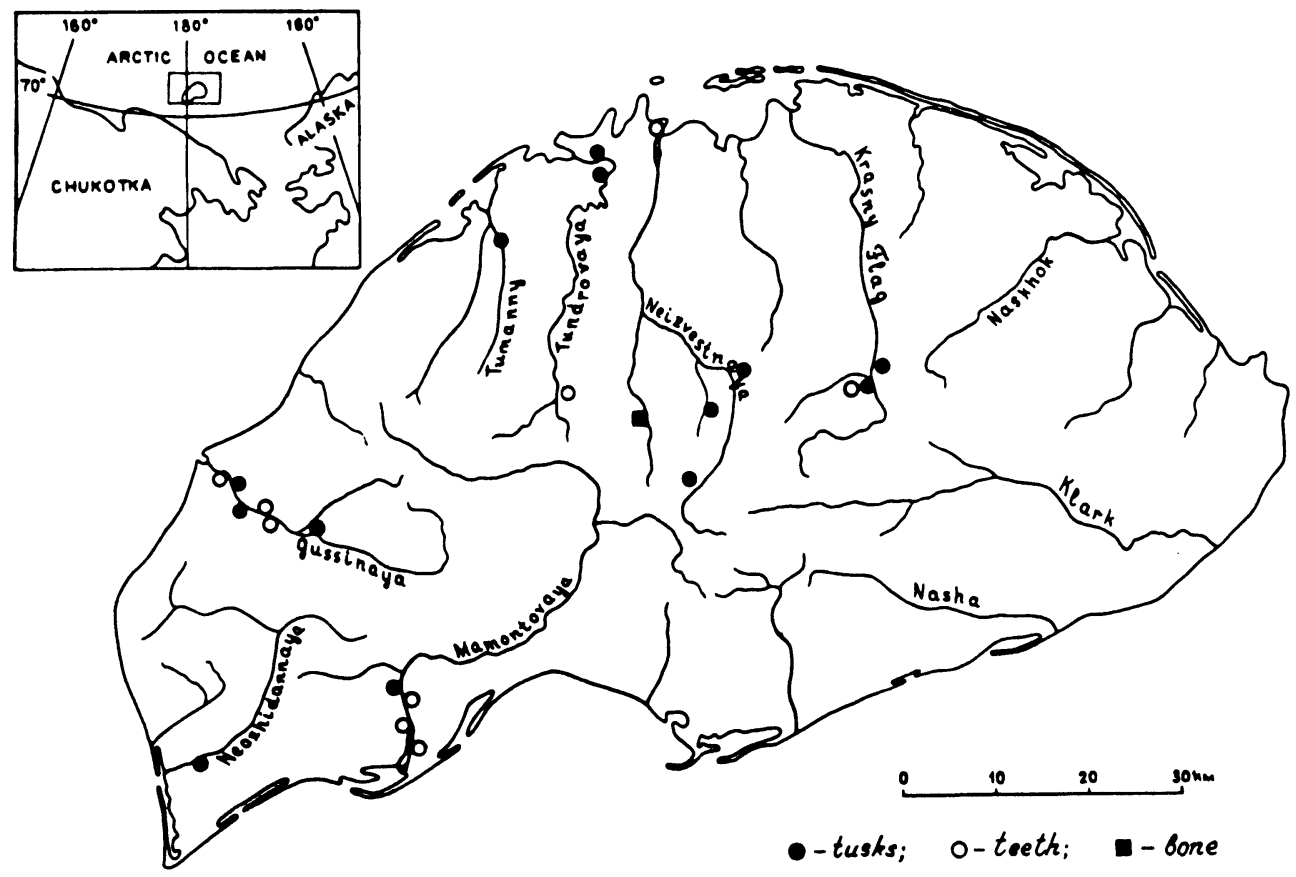

Fig. 1. Location map of Wrangel Island, showing sites of mammoth samples

\section{GEOGRAPHY OF THE SITE}

Wrangel Island is located on the border of the East-Siberian and Chukchi Seas, between $70^{\circ}$ and $72^{\circ} \mathrm{N}$, and $177^{\circ} \mathrm{E}$ and $176^{\circ} \mathrm{W}$ (Fig. 1). Ca. $8000 \mathrm{~km}^{2}$, the island is separated from the continent by the Long Strait, with a minimum width of $140 \mathrm{~km}$, and a depth of $245 \mathrm{~m}$. The eastern, western, and central portions of the island have low mountain ranges (up to $1100 \mathrm{~m}$ asl) and bisected plateaus; the northern ("Akademia Tundra") and southern portions are plains.

The Quaternary sediments of Wrangel Island are not very thick; they are primarily aleurite, sand, shingle and peat of Late Pleistocene and Holocene age. The coastal-marine sediments (in the Akademia Tundra) and the alluvium of the high terraces of large rivers, as well as the spare, heavily icebearing sand-shingle terraces of the lower hilly terrain, all seem to be of Pleistocene age. Numerous solifluction and other slope sediments of the mountainous part of the island, river-valley alluvium (floodplain and the first terraces of large rivers), and peat and lacustrine thermokarst sediments are widespread on the plains and intermontane depressions, and are of Holocene age.

Bone-rich horizons such as the "Edoma" strata in Siberia have not been found on Wrangel Island. All the bone specimens were collected from riverbed and slope sediments. Only well-preserved tusks (except for one split tusk), teeth and bones were collected. We selected teeth for dating from the collection of S. Vartanyan, made in 1991, which was previously studied by V. E. Garutt of the Zoological Institute of Russian Academy of Sciences.

\section{METHODS}

Although all samples were well preserved in frozen ground, we used stronger pretreatment than conventional to remove impurities. We extracted and purified bone collagen using a procedure devel- 
oped in our laboratory to remove both easily soluble and relatively insoluble organic contaminants (Arslanov and Svezhentsev 1993). We found that the well-known $\mathrm{HCl}-\mathrm{NaOH}$ and Longin's procedures by themselves did not sufficiently purify collagen.

We obtained carbon from the purified collagen by means of pyrolysis, then lithium carbide according to the reaction $2 \mathrm{C}+2 \mathrm{Li}-\mathrm{Li}_{2} \mathrm{C}_{2}$. Benzene synthesis was carried out using a high-efficiency vanadium-alumina-silica catalyst $\left(\mathrm{V}_{2} \mathrm{O}_{5} \cdot \mathrm{Al}_{2} \mathrm{O}_{3} \cdot \mathrm{SiO}_{2}\right)$ that enabled us to produce benzene with up to $96 \%$ yield. Sample activity was measured with a coincidence scintillation counter using quartz spherical vials ( $8.46 \mathrm{ml}$ capacity); background and modern standard count rates were $1.9 \mathrm{cpm}$ and $56.8 \mathrm{cpm}$, respectively. Our techniques for pretreatment and measurement are described in detail elsewhere (Arslanov, Tertychnaya and Chernov 1993).

\section{RESULTS AND DISCUSSION}

We dated 23 samples of Mammuthus primigenius remains from Wrangel Island. The youngest and the oldest presently known dates of mammoth remains from the Siberian Arctic and Severnaya Zemlya (Makeev, Arslanov and Garutt 1979; Arslanov et al. 1982; Lavrov and Sulerzhytsky 1992) are given in Table 1. Table 2 shows our Wrangel Island dates; 20 out of the 23 samples proved to be of Holocene age, falling within the range $3730 \pm 40$ to $7390 \pm 30$ BP. Three dates on teeth from Wrangel Island were Pleistocene in age: LU-2823, -2792 and -2807 at ca. 12, 13 and $20 \mathrm{ka}$, respectively (Table 2), when Wrangel Island was part of Beringia.

TABLE 1. Oldest and Youngest ${ }^{14} \mathrm{C}$ Dates on Mammoths of Arctic Siberia (excluding Wrangel Island)

\begin{tabular}{|c|c|c|}
\hline Material and location & Lab no. & ${ }^{14} \mathrm{C}$ age (yr BP) \\
\hline $\begin{array}{l}\text { Continent } \\
\text { Fragment of mammoth skin, Khatanga River, } \\
\text { Taimyr Peninsula }\end{array}$ & LU-1057 & $\geq 53,170$ \\
\hline $\begin{array}{l}\text { Plant debris from mammoth stomach, Yuribei } \\
\text { River, Gydan Peninsula }\end{array}$ & LU-1153 & $10,000 \pm 70$ \\
\hline $\begin{array}{l}\text { Mammoth tusk, Nizhnaya Taimyra River } \\
\text { Mammoth tooth, Nizhnaya Taimyra River }\end{array}$ & $\begin{array}{l}\text { GIN-1823 } \\
\text { GIN-1495 }\end{array}$ & $\begin{array}{l}9670 \pm 60 \\
9860 \pm 50\end{array}$ \\
\hline $\begin{array}{l}\text { Arctic Islands } \\
\text { Mammoth tusk, October Revolution Island, } \\
\text { Severnaya Zemlya Archipelago }\end{array}$ & LU-610 & $11,500 \pm 60$ \\
\hline
\end{tabular}

Geomorphological reconstruction indicates that Wrangel Island formed a part of Beringia (an area that included Chukotka, Alaska, and the huge expanse of the surrounding shelf) during the Late Pleistocene, when the global sea level was $c a .100 \mathrm{~m}$ below the present level. At the end of the Pleistocene or beginning of the Holocene, Wrangel Island separated from the continent (Hopkins 1975), becoming a refugium for the mammoth population. Our data show that this population survived as long as $6000 \mathrm{yr}$ after all mammoths on the continent were extinct. Morphological studies of mammoth teeth demonstrate that a previously unknown dwarf species of mammoth evolved on Wrangel Island (Vartanyan et al. 1993).

Three Wrangel Island mammoth teeth were found to be of Late Pleistocene age, with one sample (LU-2807) (Table 2) deriving from the period of the Late Glacial maximum ( 20,000 BP). We obtained similar dates for a mammoth tusk collected on Severnaya Zemlya Archipelago (19,270 \pm 
TABLE 2. ${ }^{14} \mathrm{C}$ Dates of Mammoth Remains from Wrangel Island

\begin{tabular}{|c|c|c|c|}
\hline Lab no. & Material, provenience & $\begin{array}{l}{ }^{14} \mathrm{C} \text { age } \\
\text { (yr BP) }\end{array}$ & $\begin{array}{c}\text { Calibrated } \\
\text { age (cal BC)* }\end{array}$ \\
\hline \multicolumn{4}{|c|}{ Tusks and Bone } \\
\hline LU-2741 & $\begin{array}{l}\text { Tusk }(8 \mathrm{~cm} \text { diameter }(\mathrm{d})) \text { from the bed of the lower } \\
\text { Neozhydannaya River }\end{array}$ & $3730 \pm 40$ & $2192-2038$ \\
\hline LU-2756 & $\begin{array}{l}\text { Tusk ( } 11 \mathrm{~cm} \mathrm{~d} \text { ) from the bed of the lower Mamon- } \\
\text { tovaya River }\end{array}$ & $4400 \pm 40$ & $3082-2924$ \\
\hline LU-2768 & Tusk $(9 \mathrm{~cm} \mathrm{~d})$ from the bed of Tumanny Creek & $4410 \pm 50$ & 3090-2924 \\
\hline LU-2556 & $\begin{array}{l}\text { Tibia bone }(0.1-0.2 \mathrm{~m}) \text { from the floodplain of the up- } \\
\text { per Lemmingovaya River }\end{array}$ & $4740 \pm 40$ & $3626-3382$ \\
\hline LU-2740 & $\begin{array}{l}\text { Tusk }(6 \mathrm{~cm} \mathrm{~d}) \text { from the bed of the lower Tundrovaya } \\
\text { River }\end{array}$ & $4900 \pm 40$ & $3706-3646$ \\
\hline LU-2745 & $\begin{array}{l}\text { Tusk }(9.5 \mathrm{~cm} \mathrm{~d}) \text { from the bed of the lower Goosinaya } \\
\text { River }\end{array}$ & $5200 \pm 30$ & 4036-3972 \\
\hline LU-2744 & Tusk from the bed of the middle Goosinaya River & $5250 \pm 40$ & $4216-3990$ \\
\hline LU-2742 & Tusk from the bed of the lower Goosinaya River & $5310 \pm 90$ & $4232-4000$ \\
\hline LU-2535 & $\begin{array}{l}\text { Tusk from left bank of the Red Flag River valley, } 2 \mathrm{~km} \\
\text { upstream from the mouth of the Otrozhnaya River }\end{array}$ & $5480 \pm 50$ & $4440-4252$ \\
\hline LU-2558 & $\begin{array}{l}\text { Tusk from diluvium-solifluction sediments on the } \\
\text { western slope of Mount Kit, left side of Neizvest- } \\
\text { naya River valley }\end{array}$ & $6610 \pm 50$ & $5567-5450$ \\
\hline LU-2736 & $\begin{array}{l}\text { Tusk from creekbed on the left side of the upper Neiz- } \\
\text { vestnaya River valley }\end{array}$ & $6760 \pm 50$ & $5666-5585$ \\
\hline LU-2746 & $\begin{array}{l}\text { Tusk }(7 \mathrm{~cm} \mathrm{~d}) \text { from the bed of the lower Tundrovaya } \\
\text { River }\end{array}$ & $7040 \pm 60$ & $5954-5816$ \\
\hline LU-2559 & Tusk from the bed of middle Vetvisty Creek & $7360 \pm 50$ & $6214-6062$ \\
\hline LU-2444 & $\begin{array}{l}\text { Tusk from the right side of Red Flag River valley, area } \\
\text { of the mouth of the Otrozhnaya River }\end{array}$ & $7390 \pm 30$ & $6216-6176$ \\
\hline \multicolumn{4}{|c|}{ Teeth } \\
\hline LU-2798 & $\begin{array}{l}\text { Last upper molar from the bed of the lower Mamon- } \\
\text { tovaya River (N-MAM- } 6)\end{array}$ & $4010 \pm 50$ & $2574-2464$ \\
\hline LU-2808 & $\begin{array}{l}\text { Tooth fragment from the bed of the lower Mamon- } \\
\text { tovaya River (N-MAM-2) }\end{array}$ & $4040 \pm 30$ & $2582-2492$ \\
\hline LU-2794 & $\begin{array}{l}\text { Last lower molar from the bed of the lower Mamon- } \\
\text { tovaya River (N-MAM-5) }\end{array}$ & $5110 \pm 40$ & $3966-3812$ \\
\hline LU-2799 & $\begin{array}{l}\text { Last lower molar from the bed of the lower Goosinaya } \\
\text { River (N-GUS-9) }\end{array}$ & $6260 \pm 50$ & $5262-5088$ \\
\hline LU-2810 & $\begin{array}{l}\text { Tooth fragment from the bed of the lower Goosinaya } \\
\text { River (N-GUS-9) }\end{array}$ & $6890 \pm 50$ & $5766-5672$ \\
\hline LU-2809 & $\begin{array}{l}\text { Last lower molar from the bed of the upper Tundro- } \\
\text { vaya River }\end{array}$ & $7250 \pm 60$ & $6158-5988$ \\
\hline LU-2823 & $\begin{array}{l}\text { Last lower molar from the bed of the lower Goosinaya } \\
\text { River (N-GUS-8) }\end{array}$ & $12,010 \pm 110$ & $12,200-11,925$ \\
\hline LU-2792 & $\begin{array}{l}\text { Last lower molar from the bed of the middle Red Flag } \\
\text { River }\end{array}$ & $12,980 \pm 80$ & $13,580-13,325$ \\
\hline LU-2807 & $\begin{array}{l}\text { Last lower molar found on a beach, } 1 \mathrm{~km} \text { from the } \\
\text { mouth of the Neizvestnaya River }\end{array}$ & $20,000 \pm 110$ & -- \\
\hline
\end{tabular}


$130 \mathrm{BP}$ ) (Makeev, Arslanov and Garutt 1979), and for a front leg-bone found at the mouth of the Lena River, on the Bykovsky Peninsula (21,630 $\pm 240 \mathrm{BP}$, LU-1328, Tomirdiaro et al. 1984). All of these data support the thesis that during the last glacial maximum, conditions in the East-Siberian Arctic and on the northern islands were adequate for habitation by mammoths.

\section{ON THE RELIABILITY OF MAMMOTH DATES}

How reliable are these Wrangel Island dates? The question is legitimate: bone is difficult to date, due to its high potential for absorbing external humid acids from groundwater. However, all our mammoth samples were well preserved and were collected from frozen ground. We used a reliable procedure for the chemical treatment of the bone (Arslanov and Svezhentsev 1993), which permitted us to obtain a collagen purified of organic contaminants, whatever their solubility. In addition, the viability of our methods and measurements is supported by our dating of a series of samples for interlaboratory quality control supplied by the International Agency for Atomic Energy (IAEA) and by Glasgow University, the Third International Radiocarbon Intercomparison (TIRI) (Scott et al. 1992). All of our dates (Table 3) were in accordance with the control figures, within the limit of double-measurement uncertainties.

TABLE 3. Measurements of ${ }^{14} \mathrm{C}$ Activity and Age Determination of TIRIControl Samples

\begin{tabular}{clcc}
\hline $\begin{array}{c}\text { TIRI } \\
\text { code }\end{array}$ & Material & $\begin{array}{c}\text { St. Petersburg } \\
\text { measurements }\end{array}$ & TIRI mean values \\
\hline A & Grain & $117.02 \pm 0.57 \%$ & $116.12 \%$ \\
B & Wood & $4580 \pm 40 \mathrm{BP}$ & $4486 \mathrm{BP}$ \\
C & Cellulose & $129.27 \pm 0.58 \%$ & $129.81 \%$ \\
D & Peat & $3730 \pm 40 \mathrm{BP}$ & $3799 \mathrm{BP}$ \\
E & Humic acid & $10,980 \pm 70 \mathrm{BP}$ & $11,066 \mathrm{BP}$ \\
F & Iceland double spar & $250,000 \mathrm{BP}$ & $\geq 46,076 \mathrm{BP}$ \\
G & Wood & $251,560 \mathrm{BP}$ & $\geq 42,962 \mathrm{BP}$ \\
H & Peat & $11,130 \pm 40 \mathrm{BP}$ & $11,115 \pm 116 \mathrm{BP}$ \\
I & Travertine & $11,170 \pm 80 \mathrm{BP}$ & $11,034 \pm 127 \mathrm{BP}$ \\
J & Wood & $1590 \pm 40 \mathrm{BP}$ & $1593 \pm 50 \mathrm{BP}$ \\
K & Carbonate & $18,400 \pm 140 \mathrm{BP}$ & $18,166 \pm 238 \mathrm{BP}$ \\
L & Whalebone & $12,580 \pm 60 \mathrm{BP}$ & $12,605 \pm 127 \mathrm{BP}$ \\
\hline
\end{tabular}

Later, 2 teeth and 1 tusk from Wrangel Island were dated at The University of Arizona Radiocarbon Laboratory (AA) (Long, Sher and Vartanyan 1994) and by L. Sulerzhitsky in the laboratory of the Geological Institute of the Russian Academy of Sciences (GIN). The data shown in Table 4 are in excellent agreement and, along with data from the Third International Radiocarbon Intercomparison (TIRI), these measurements confirm the reliability of our dates.

TABLE 4. Age determinations of Wrangel Island Mammoth Remains: Results of Three Laboratories

\begin{tabular}{llc}
\hline Sample & \multicolumn{2}{c}{ Age and sample number } \\
\hline GUS-9, tooth & $6260 \pm 50$, LU-2799 & $6360 \pm 60$, AA-11529 \\
PIK-1, tooth & $7250 \pm 60$, LU-2809 & $7295 \pm 95$, AA-11530 \\
20-M, tusk & $6760 \pm 50$, LU-2736 & $6750 \pm 30$, GIN-6990 \\
\hline
\end{tabular}




\section{CONCLUSION}

During the last glacial maximum (ca. $20 \mathrm{ka}$ ago), environmental conditions on Wrangel Island proved capable of sustaining habitation by mammoths. Our data show that woolly mammoths persisted on Wrangel Island in the mid-Holocene, from $7390-3730$ yr ago. ${ }^{14} \mathrm{C}$ dating has shown that mammoths inhabited Wrangel Island for as long as $6000 \mathrm{yr}$ after the estimated extinction of Mammuthus primigenius on the Siberian continent.

\section{REFERENCES}

Arslanov, Kh. A., Liadov, U. U., Filonov, B. A. and Chernov, S. B. 1982 On the absolute age of the Yuribei Mammoth. In Sokolov, V. E., ed., Yuribeisky Mamont [The Yuribei Mammoth]. Moscow, Nauka: 35-36 (in Russian).

Arslanov, Kh. A. and Svezhentsev, Yu. S. 1993 An improved method for radiocarbon dating fossil bones. Radiocarbon 35(3): 387-391.

Arslanov, Kh. A., Tertychnaya, T. U. and Chernov, S. B. 1993 Problems and methods of dating low-activity samples by liquid scintillation counting. Radiocarbon 35(3): 393-398.

Arslanov, Kh. A., Vereschagin, N. K., Liadov, V. V. and Ukraintzeva, V. V. 1980 On the Kargino interglacial chronology and Siberian landscape reconstruction by the study of mammoth carcasses and mammoth "satellite" animals. In Ivanova, I. K. and Kind, N. V., eds., Geochronologia Chetvertichnogo Perioda [Geochronology of the Quaternary Period]. Moscow, Nauka: 208-213.

Arslanov, Kh. A., Voznjachuk, L. N., Kalechits, E. G. and Kolesnikov, V. S. 1972 Radiocarbon dates of Paleolithic sites of the Dnepr River valley. Bulleten Komissii po Izucheniyu Chetvertichnogo Perioda [Bulletin of the Commission for the Study of the Quaternary] 39: 163-165.

Hopkins, D. M. 1975 Sea level history in Beringia during the last 25000 yrs. In Kontrimavichus, V. L., ed., Beringia $v$ Kainosoye [Beringia in the Cenozoic]. Vladivostok, Akademiia nauk SSSR: 2-27.

Lavrov, A. V. and Sulerzhytsky, L. D. 1992 Mammoths: Radiocarbon dates on the time of their habitation. In Vekovaya Dinamica Biogeozenosov [Secular Dynamics of Biogeocenosis]. The 10th Sukachev Reading.
Moscow, Nauka: 36-52 (in Russian).

Long, A., Sher, A. and Vartanyan, S. 1994 Holocene mammoth dates. Nature 369: 364.

Makeev, V. M., Arslanov, Kh. A. and Garutt, V. E. 1979 The age of mammoths of Severnaya Zemlya and some problems of the paleogeography of the Late Pleistocene. Doklady Akademii Nauk SSSR 245(2): 421-424.

Scott, E. M., Harkness, D. D., Miller, B. F., Cook, G. T and Baxter, M. S. 1992 Announcement of a further international intercomparison exercise. In Long, A. and Kra, R. S., eds., Proceedings of the 14th International ${ }^{14} \mathrm{C}$ Conference. Radiocarbon 34(3): 528-532.

Stuart, A. J. 1991 Mammalian extinctions in the Late Pleistocene of northern Eurasia and North America. Biological Reviews 66: 453-562.

Tomirdiaro, S. V., Arslanov, Kh. A., Chernenky, B. J., Tertychnaya, T. V. and Prokhorova T. N. 1984 New data about the formation of loess-ice strata in Northern Yakutia and conditions of mammoth fauna habitation in the Arctic during the Late Pleistocene. Doklady Akademii Nauk SSSR 278(6): 1446-1449 (in Russian).

van der Plicht, J. The Groningen radiocarbon calibration program. In Stuiver, M., Long, A., and Kra, R. S., ed., Calibration 1993. Radiocarbon 35(1): 231-237.

Vartanyan, S. L., Arslanov, Kh. A., Tertychnaya, T. V. and Chernov, S. B. 1992 Radiocarbon age of Holocene mammoths of Wrangel Island. In Vekovaya Dinamica Biogeozenosov [Secular Dynamics of Biogeocenosis]. The 10th Sukachev Reading. Moscow, Nauka: 52-53 (in Russian).

Vartanyan, S. L., Garutt, V. E. and Sher, A.V. 1993 Holocene dwarf mammoths from Wrangel Island in the Siberian Arctic. Nature 362: 337-340. 